\title{
A review of the endemic chameleon genus Brookesia from Madagascar, and the rationale for its listing on CITES Appendix II
}

\author{
Angus I. Carpenter and Onja Robson
}

\begin{abstract}
The chameleon genus Brookesia, with 26 species, is endemic to Madagascar. The main threats to Brookesia are habitat destruction and collection for trade. At the CITES Conference of Parties 12, held in Santiago, Chile in 2002, all but one Brookesia species were added to Appendix II, under which trade is controlled in order to avoid utilization being incompatible with species' survival. The Vulnerable B. perarmata was added to Appendix I, under which trade is permitted only in exceptional circumstances. Summary information for Brookesia is presented here, reviewing taxonomy, habitat preferences, available population estimates, relevant legislation, major threats, and trade levels. Brookesia live on or close to the ground, with roost sites mostly $<1 \mathrm{~m}$ above ground. Density estimates are available for only a few
\end{abstract}

species, with a mean density estimate for four species across sites and seasons of 16 individuals ha ${ }^{-1}$. A number of species have distinct altitudinal ranges, and a preference for primary forest. Continued deforestation will therefore potentially lead to extirpations. Research on population sizes and seasonal trends of Brookesia is required, without which, combined with data on the impacts of harvesting, the establishment of sustainable trade will not be possible. The apparent reduction and possible cessation of trade in B. perarmata following its listing on CITES indicates that the Convention can succeed in managing global trade in a threatened species.

Keywords Brookesia, chameleon, CITES, Madagascar, wildlife trade.

\section{Introduction}

Trade in wildlife is monitored through the Convention on International Trade in Endangered Species of Wild Fauna and Flora (CITES). At the CITES Conference of Parties (CoP) 12, held in Santiago, Chile in 2002 chameleons of the genus Brookesia were added to Appendix II, under which trade is controlled to avoid utilization compromising species' survival. The Vulnerable $B$. perarmata (IUCN, 2004) was added to Appendix I, under which trade is permitted only in exceptional circumstances. Chameleon species other than those in the genera Rhampholeon and Brookesia have been included on Appendix II since the early 1970s (Rosser et al., 2001).

Conservation concerns for chameleons arise primarily from habitat destruction and secondarily from trade (JNCC, 1993; Brady \& Griffiths, 1999). Using data from the CITES Trade Database (UNEP-WCMC, 2005) a

Angus I. Carpenter* (Corresponding author) Centre for Ecology, Evolution and Conservation, School of Environmental Sciences, University of East Anglia, Norwich, NR4 7TJ, UK. E-mail chameleon.project@uea.ac.uk

Onja Robson Department de Biologie Animale, Faculte des Sciences, Université d'Antananarivo, Antananarivo, Madagascar.

*Also at: Institute of Zoology, Zoological Society of London, Regent's Park, London, NW1 4RY, UK.

Received 8 July 2004. Revision requested 4 January 2005. Accepted 7 March 2005. review of the dynamics of the global trade in chameleons has been conducted for species in the genera Furcifer, Bradypodion, Calumma and Chamaeleo (Carpenter et al., 2004). Because Brookesia was not listed on a CITES Appendix trade was not officially monitored, although some trade data were provided voluntarily by member states.

A summary of the taxonomy, ecology, distribution and available trade data for Brookesia was provided for Party members at $\mathrm{CoP} 12$, but the summary was not available to all CoP 12 participants or to interested conservationists and researchers. This summary information is presented here, reviewing taxonomy, habitat preferences, available population estimates, relevant legislation, major threats, and trade levels.

\section{Taxonomy, ecology \& distribution}

The family Chamaeleonidae contains two subfamilies, Brookesiinae and Chamaeleoninae, and six genera (Uetz, 2004). Within the Brookesiinae there are two genera, Brookesia and Rhampholean. The 26 species of Brookesia (Table 1) are endemic to Madagascar (Uetz, 2004). A summary of the biology and ecology of the species is presented in Table 2. Raxworthy \& Nussbaum (1995), Glaw et al. (1999) and Glaw \& Vences (1994) provide taxonomic information.

Confusion exists concerning the relationship Brookesia has with its environment, leading to statements that 
Table 1 Summary of Brookesia taxonomy and distribution, extracted from http://srs.embl-heidelberg.de:8000/srs5bin/cgi-bin/ wgetz?[REPTILIA-Species:Brookesia*] [accessed 10 August 2005].

\begin{tabular}{|c|c|c|c|}
\hline Species & Synonyms & Distribution & Comments* \\
\hline B. ambreensis & & Montagne de Ambre National Park & Holotype UMMZ 203635 \\
\hline B. antakarana & & Montagne de Ambre National Park & Holotype UMMZ 200071 \\
\hline B. bekolosy & & Manongarivo Special Reserve, Bekolosy & Holotype UMMZ 200078 \\
\hline B. betschi & & Medium altitude $(1,300 \mathrm{~m})$ forest at Marojezy & \\
\hline B. bonsi & & Tsingy de Namoroka, Soalala & Holotype MHNP 1978.1992. \\
\hline B. brygooi & & SW Madagascar & Holotype MHNP 8219 \\
\hline B. decaryi & & Ankarafantsika Massif, NW Madagascar & Syntypes MHNP 1938. 158-162 \\
\hline B. dentata & B. ramanantsoai & NW Madagascar & $\begin{array}{l}\text { Holotype MHNP 99.322; } \\
\text { B. dentata and B. ramanantsoai } \\
\text { synonymized by Raxworthy } \\
\text { \& Nussbaum (1995) }\end{array}$ \\
\hline B. ebenaui & $\begin{array}{l}\text { Chamaeleo ebenaui, } \\
\text { B. legendrei }\end{array}$ & Nosy Bé & Holotype SMF 16515 \\
\hline B. exarmata & & Tsingy de Bemaraha, W Madagascar & \\
\hline B. griveaudi & & NE Madagascar & \\
\hline B. karchei & & Massif du Marojezy & \\
\hline \multicolumn{4}{|l|}{ B. lambertoni } \\
\hline B. lineata & & Manongarivo Special Reserve, Bekolosy & Holotype UMMZ 200073 \\
\hline B. lolontany & & Tsaratanana Mt. & Holotype UMMZ 203629 \\
\hline B. minima & & NW Madagascar and Nosy Bé & $\begin{array}{l}\text { B. minima, B. tuberculata and } \\
\text { B. peyrierasi synonymized by } \\
\text { Raxworthy \& Nussbaum (1995), } \\
\text { but reversed by Glaw et al. (1999) }\end{array}$ \\
\hline B. nasus & $\begin{array}{l}\text { B. nasus, B. betsileana, } \\
\text { Evoluticauda nasus } \\
\text { Subspecies: } \\
\text { B. nasus pauliani, } \\
\text { B. nasus nasus }\end{array}$ & $\begin{array}{l}\text { Ekongo, Manjarivolo, l'Andringitra, } \\
\text { SE Madagascar }\end{array}$ & \\
\hline B. perarmata & Leandria perarmata & W Madagascar & Holotype MNHP 1935-145 \\
\hline B. peyrierasi & B. minima & NE Madagascar & $\begin{array}{l}\text { Holotype MHNP 1968.190; } \\
\text { B. minima, B. tuberculata, and } \\
\text { B. peyrierasi synonymized by } \\
\text { Raxworthy \& Nussbaum (1995), } \\
\text { but reversed by Glaw et al. (1999) }\end{array}$ \\
\hline B. stumpffi & & Nosy Bé and NW Madagascar & Lectotype SMF 16475 \\
\hline B. superciliaris & $\begin{array}{l}\text { Chamaeleo superciliaris, } \\
\text { C. brookesianus, } \\
\text { C. brookesia, } \\
\text { C. brookesii, C. brookesiana }\end{array}$ & E Madagascar & \\
\hline B. therezieni & & E Madagascar & \\
\hline B. thieli & B. antoetrae & E \& N Madagascar & $\begin{array}{l}\text { B. antoetrae synonymized } \\
\text { with B. thieli (Raxworthy } \\
\text { \& Nussbaum, 1995) }\end{array}$ \\
\hline B. tuberculata & B. minima & N Madagascar & $\begin{array}{l}\text { Holotype MHNP 93.183.; } \\
\text { B. minima, B. tuberculata \& } \\
\text { B. peyrierasi synonymized } \\
\text { (Raxworthy \& Nussbaum, 1995), } \\
\text { but later reversed (Glaw et al., 1999) }\end{array}$ \\
\hline B. vadoni & & Near Masoala & \\
\hline B. valerieae & & Manongarivo Special Reserve & \\
\hline
\end{tabular}

*Types are only provided for those that have been traced. MHNP, Muséum National d'Histoire Naturelle, Paris; UMMZ, University of Michigan, Museum of Zoology; SMF, Senckenberg Museum, Frankfurt.

species are incapable of adjusting to environmental change (Necas, 1999) or, conversely, are highly adaptable (LeBerre, 1995). Brookesia are known, however, to be restricted to discrete attitudinal zones within a range of $0-2,050 \mathrm{~m}$ altitude, to occur mostly in primary forest, and to occupy distinct roost sites within the chameleon assemblage (Raxworthy \& Nussbaum, 1995; Carpenter, 2003). Roost sites are considered good indicators of the 
Table 2 A summary of the distribution, ecology and biology of those Brookesia spp. for which information is readily available.

\begin{tabular}{|c|c|}
\hline Species & \\
\hline B. ambreensis & $\begin{array}{l}\text { Possibly endemic to Montagne d'Ambre, in primary rainforest over } 650-1150 \mathrm{~m} \text {. Males (snout-vent length, SVL, } \\
44-52 \mathrm{~mm} \text { ) smaller than females (SVL 52-55 mm) although sample size was small (Raxworthy \& Nussbaum, 1995). }\end{array}$ \\
\hline B. antakarana & $\begin{array}{l}\text { On Montagne d'Ambre \& also considered endemic to northern Antakarana. Found in rainforest at } 650-1200 \mathrm{~m} \text {, it roosts } \\
\text { between ground level \& } 1.5 \mathrm{~m} \text { (Raxworthy \& Nussbaum, 1995). }\end{array}$ \\
\hline B. bekolosy & $\begin{array}{l}\text { Only a single male ( } 34 \mathrm{~mm} \text { SVL) has been recorded, collected from primary forest at 1,200 } \mathrm{m} \text { on the Bekolosy plateau at } \\
\text { Manongarivo, with a roost site } 1 \mathrm{~m} \text { above ground (Raxworthy \& Nussbaum, 1995). }\end{array}$ \\
\hline B. brygooi & $\begin{array}{l}\text { At Analavelona, Sakaraha, Kasijy \& near Toliara, SW Madagascar. Brygoo is cited (in Raxworthy \& Nussbaum, 1995) as } \\
\text { recording the species in Reserve Naturelle Integrale No. 11, Bemaraha \& Antsalova. Maximum SVL of males } 52 \mathrm{~mm} \\
\text { (tail } 38 \mathrm{~mm} \text { ) \& females } 48 \mathrm{~mm} \text { (tail } 33 \mathrm{~mm} \text { ). Found in the arid SW \& W, it is one of the few Brookesia adapted to arid } \\
\text { environments \& is probably restricted to native deciduous forests in these regions (Raxworthy \& Nussbaum, 1995). }\end{array}$ \\
\hline B. decaryi & $\begin{array}{l}\text { Only a small range, located at Ankarafantsika, NW Madagascar, where there are significant seasonal changes in climate \& } \\
\text { vegetation, \& abundance is apparently linked to these fluctuations (Carpenter, 2003). }\end{array}$ \\
\hline B. ebenaui & $\begin{array}{l}\text { Described from the isand of Nosy Bé in 1893. Inhabits humid \& secondary growth forest \& considered more arboreal than } \\
\text { its congeners. Often labelled B. legendrei, which was considered a junior synonym for B. ebenaui, in pictures of the } \\
\text { species. }\end{array}$ \\
\hline B. exarmata & In Tsingy de Bemaraha, W Madagascar. Occurs sympatrically with B. brygooi \& B. perarmata. Described in 1996. \\
\hline B. lineata & $\begin{array}{l}\text { Unusual for Brookesia, with flanks marked by bold, dark brown, longitudinal lines. Only one individual recorded, from } \\
\text { Bekolosy, Manongarivo Special Reserve at 1,200 m, with SVL of } 45 \mathrm{~mm} \text {. Not known from any other localities, \& was } \\
\text { recorded in primary forest roosting } 1 \mathrm{~m} \text { above ground (Raxworthy \& Nussbaum, 1995). }\end{array}$ \\
\hline B. lolontany & $\begin{array}{l}\text { In the Tsaratanana Mountains, N Madagascar. Two females were collected at 2,050 \& 1,600 m from primary forest, one } \\
\text { dominated with bamboo, roosting at } 0.7 \& 0.05 \mathrm{~m} \text { above ground, with SVLs of } 32 \mathrm{~mm} \text { (tail } 18 \mathrm{~mm} \text { ) \& } 28 \mathrm{~mm} \text { (tail } \\
15 \mathrm{~mm} \text {; Raxworthy \& Nussbaum, 1995). }\end{array}$ \\
\hline B. minima & $\begin{array}{l}\text { Forms a species group with B. dentate \& B. tuberculata. Considered the smallest of all Chamaeleonidae, it inhabits the floor } \\
\text { of rainforest on the island of Nosy Bé. Also recorded at Anjajavy, in 2000-2001, on the coast of NW Madagascar } \\
\text { (Carpenter, 2003). Males smaller \& more slender than females. }\end{array}$ \\
\hline B. perarmata & $\begin{array}{l}\text { In the Antsingy region of Menabe Province, W Madagascar. Inhabits bushes \& the forest floor, \& attains a total length of } \\
110 \mathrm{~mm} \text {. Distinguished by bilateral rows of thorny spines along the dorsal surface. }\end{array}$ \\
\hline B. thieli & In E central Madagascar \& considered locally abundant, inhabiting the rainforest floor. \\
\hline B. stumpffi & $\begin{array}{l}\text { On Nosy Bé in leaf litter \& rotting tree trunks on the rainforest floor. Carpenter (2003) also recorded the species in dry } \\
\text { forests \& disturbed sites along the coast of NW Madagascar. One of the larger Brookesia, with a total length of up to } \\
100 \mathrm{~mm} \text {. }\end{array}$ \\
\hline B. superciliaris & $\begin{array}{l}\text { Inhabits the rainforest floor in coastal regions of E Madagascar \& the island of Nosy Boraha. One of the larger Brookesia, } \\
\text { with a total length of up to } 100 \mathrm{~mm} \text {. }\end{array}$ \\
\hline
\end{tabular}

foraging locations of chameleons (Akani et al., 2001). Brookesia are generally cited as being terrestrial (Glaw \& Vences, 1994), and roost sites are consistently lower than in other chameleon genera (Carpenter, 2003). B. stumpffi has the highest recorded roost sites (mean height $0.43 \mathrm{~m}$ $\pm 0.34 \mathrm{SD}$ ), but still $>2 \mathrm{~m}$ lower than co-occurring Fucifer angeli. Brookesia decaryi has the lowest recorded roost sites, (mean height $0.17 \mathrm{~m} \pm 0.08 \mathrm{SD}$; Carpenter, 2003).

Studies of Brookesia have mostly focused on sitespecific inventories (Raxworthy, 1988; Raxworthy \& Nussbaum, 1995), with little known about the abundance of individual species. Available abundance and density estimates have been used to indicate preferred habitats but there is a lack of agreement between studies, even for the same species. For example, B. nasus has been recorded in higher numbers than conspecifics in both slightly disturbed habitats (Jenkins et al., 1999) and undisturbed riparian forest (Jenkins et al., 2003). Anthropogenic factors can affect Brookesia abundance. At Andranomay, for example, abundance was higher in undisturbed sites (B. thieli, 58 ha $^{-1}$; B. minima, 7 ha $^{-1}$ ) compared to burnt sites (B. thieli, 20 ha $^{-1}$; B. minima, 0.0 ha $^{-1}$; Rabearivony, 1999). Brookeisa abundance also fluctuates between seasons. At Ranomafana National Park, for example, density estimates were greater in the summer (B. superciliaris 39 ha $^{-1}, B$. nasus 41 ha $^{-1}, B$. thieli $<0.1 \mathrm{ha}^{-1}$ ) compared to the winter (B. superciliaris 14 ha $^{-1}$, B. nasus 6 ha $^{-1}$, B. thieli $<0.1$ ha $^{-1}$ ) (Rabearivony, 1999).

No studies are currently investigating population sizes or trends in any species of Brookesia. Attempts to record abundance have encountered persistent problems with either too little or no data (Ramilison \& Rabibisoa, 1998; Rabearivony, 1999), often due to a combination of factors such as censusing difficulties, availability of suitable habitat and the low densities of some species. Rabearivony (1999) combined data for several species, generating density estimates of the genus that varied between zero and 74 individuals $\mathrm{ha}^{-1}$, and a mean density estimate for four species across sites and seasons of only 16 individuals ha ${ }^{-1}$. 


\section{Threats, legislation and trade}

The main threats to Brookesia are habitat destruction and trade. Habitat destruction is a major threat to all flora and fauna on Madagascar, and in contrast to the application of conservation efforts, greater areas of seasonal forest have been lost in recent years compared to rainforest (Whitmore, 2000). In western Madagascar only $1 \%$ of natural relict forest, in this deciduous forest region, is under any form of protection, and a total area of only c. $11,000 \mathrm{~km}^{2}$ is under protection in all of Madagascar (ANGAP, 2001).

Harvesting of Brookesia for the pet trade has been recorded within protected areas (Ramilison \& Rabibisoa, 1998) although harvesting is not the main threat to $B$. nasus in Ranomafana National Park (Jenkins et al., 1999). Limited information has been recorded on the economic or network structures of trade (Ramilison \& Rabibisoa, 1998; Brady \& Griffiths, 1999; Rabearivony, 1999), although details of both network and economic structures has been recorded for other genera (Carpenter, 2003; Carpenter et al., 2005). This showed that those involved in the 'true' chameleon trade were also trading in Brookesia. A survey of pet shops advertising Brookesia species for sale on the internet in 1999 recorded nine species (Rabearivony, 1999), whereas a similar survey in 2004 found only two websites (one advertising $B$. perarmata and one advertising B. superciliaris, for $\$ 49.99$ each).

In Madagascar the Ministère des Eaux et Forêts stipulates that the collection of B. perarmata is not permitted. This notification is provided on the reverse of collection permits issued by the Ministry to exporters. Under EC regulation No.338/97, seven species (B. decaryi, B. ebenaui, B. minima, B. perarmata, B. stumpffi, B. superciliaris and $B$. thieli) are listed under the European classification of ' $D$ '. The annex ' $\mathrm{D}$ ' monitoring system is intended as an early detection of possible conservation concern in species not listed on CITES (JNCC, 2001). In January 2004, at the 28th meeting of the EU Scientific Review Group in Brussels, under Articles 4.1(a)(i) and 4.2(a) of Regulation 338/97, a decision to refuse subsequent import applications for wild taken specimens of $B$. decaryi and $B$. thieli from Madagascar was implemented (UK CITES, 2004).

The government of Madagascar dictates that exporters submit applications prior to the export of any wildlife consignment to the Ministère des Eaux et Forêts and the Ministère de l'Élevage. These applications include CITES permits, Certificat sanitaire pour l'exportation des animaux vivants, orders for non-CITES species and invoice documentation, which are filed with both ministries. I extracted data from these documents on the species and number of individuals reported as exported in 2001, the only year for which records were available when I searched in 2002. Data were also extracted from the US Law Enforcement Management Information System
(LEMIS), providing a data set to review reported imports to the USA between 1996 and 2001, and from UNEPWCMC (2005), complied on 5 July 2004 .

Between 1996 and 2001 the LEMIS data reported a total of c. 4,000 individual Brookesia imported to the USA, whereas in 2001 only, Madagascar data reported a total of c. 3,000 individuals exported. Between 1997 and 2003 CITES data reported a total of c. 2,500 Brookesia, of which Germany accounted for $46 \%$ of imports, followed by the USA $(16 \%)$ and UK (15\%). However, there are potential problems with CITES data, with 6 month reporting delays and export data often extracted from CITES permits rather than actual trade (Jenkins \& Broad, 1994; Harwood, 1999; Carpenter, 2003). LEMIS data show Brookesia imports to the USA decreased by an order of magnitude in 1998-1999, but increased greatly again in 2000 (Fig. 1). The LEMIS and CITES data report similar values for 1997 and 1999, indicating that either the USA imported nearly all Brookesia or it was the only country to report trade. LEMIS data fluctuates greatly between years compared with CITES data. Madagascar export data for 2001 show trade nearly four times higher than the corresponding LEMIS data and nearly six times higher than the corresponding CITES data (Fig. 1).

The total number of species recorded in data sets differs. The LEMIS and CITES data record eight species and the Malagasy data 12 species (Table 3). Malagasy data record four species that are not in the LEMIS data (B. felix, B. thieli, B. vadoni and B. legendrei), and four that are not in the CITES data (B. felix, B. brygooi, B. therezieni and $B$. legendrei). However, names used by some exporters, such as B. legendrei as a synonym for B. ebenaui (Table 1 ), result in mislabelling of consignments. Moreover, importing states appear to record consignment contents only in taxonomic classifications they agree with. Therefore, only $B$. ebenaui has been recorded in CITES or LEMIS data, as $B$. legendrei is not a recognized name. Similarly, because $B$. ramanantsoai is a synonym for $B$. dentata, a similar situation appears to have occurred, with importing states only recording $B$. denata. Of the 26 species, 10 $(38 \%)$ are reported to be exported from Madagascar. One species, B. felix, is recorded in trade data but is not included in Table 1; the legitimacy of B. felix is in debate (F. Glaw, pers. comm.).

Between 1996 and 2001 LEMIS data were recorded every year for B. superciliaris and unidentified Brookesia species. Known species were traded on average for 3 years in this period, with B. ramanantsoai and B. therezieni recorded in only 1 year. The species with the highest total number of individuals imported to the USA during this period was B. perarmata $(2,215)$ followed by $B$. superciliaris (797). These two species account for nearly $75 \%$ of the total number of known individuals $(4,055)$ imported to the USA. The same two species account for c. $40 \%$ of the export figure from Madagascar in 2001, and when 


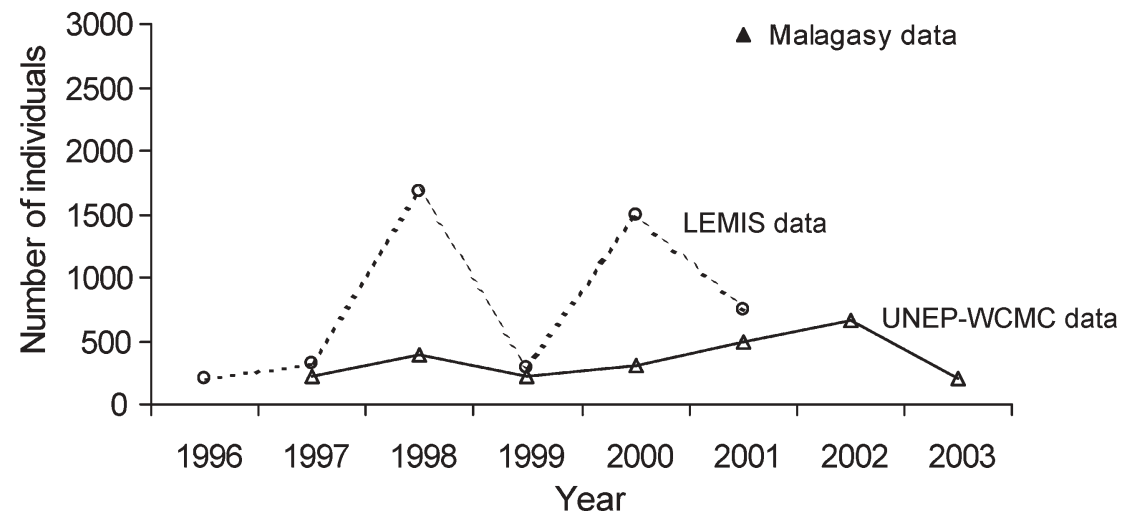

Fig. 1 The total number of individuals of Brookesia recorded as imported per year to the USA during 1996-2001 (from the US Law Enforcement Management Information System), exported from Madagascar in 2001 (from the Ministère des Eaux et Forêts), and exported from Madagascar during 1997-2003 (from UNEP-WCMC, 2005) (see text for details). combined with B. decaryi and B. thieli account for $>71 \%$ of the total export figure. Between 1997 and 2003, four species (B. superciliaris, 35\%; B. thieli, 25\%; B. perarmata, $15 \%$; $B$. decaryi, $10 \%$ ) accounted for $85 \%$ of the CITES trade figure. CITES data sets are dynamic (see Carpenter, 2003, for details), but data recorded for B. perarmata in 2002 (24) and 2003 (3) are the lowest and third lowest on record. This suggests that trade in this species is ceasing since its addition to CITES Appendix I in 2002.

The Malagasy government officially assigns minimum export values to Brookesia of USD 15 each, except $B$. perarmata and B. vadoni, which are assigned USD 64 each. Using these minimum export values the revenues generated using Madagascar export data total c. USD 75,000 for 2001 only. The LEMIS data total USD 179,260 for the

Table 3 Total number of individuals of Brookesia species recorded as imported to the USA during 1996-2001 (from the US Law Enforcement Management Information System), exported from Madagascar in 2001 (from the Ministère des Eaux et Forêts), and exported from Madagascar during 1997-2003 (from UNEP-WCMC, 2005) (see text for details). B. felix, B. legendrei and B. ramanantsolai are not in Table 1 ; see text for explanation.

\begin{tabular}{|c|c|c|c|}
\hline Species & $\begin{array}{l}\text { Imported } \\
\text { to USA, } \\
\text { 1996-2001 }\end{array}$ & $\begin{array}{l}\text { Exported from } \\
\text { Madagascar, } \\
2001\end{array}$ & $\begin{array}{l}\text { Exported from } \\
\text { Madagascar, } \\
\text { 1997-2003 }\end{array}$ \\
\hline B. brygooi & & 60 & \\
\hline B. decaryi & 214 & 457 & 262 \\
\hline B. ebenaui & 378 & 162 & 21 \\
\hline $\begin{array}{l}\text { B. felix (status } \\
\text { uncertain) }\end{array}$ & & 20 & \\
\hline $\begin{array}{l}\text { B. legendrei } \\
\quad(=\text { B. ebenaui })\end{array}$ & & 50 & \\
\hline B. minima & 342 & 162 & 180 \\
\hline B. perarmata & 2215 & 573 & 375 \\
\hline $\begin{array}{l}\text { B. ramanantsolai } \\
\quad(=\text { B. dentata })\end{array}$ & 20 & & \\
\hline B. stumpffi & 79 & 240 & 142 \\
\hline B. superciliaris & 797 & 522 & 872 \\
\hline B. therezieni & 10 & 50 & \\
\hline B. thieli & & 411 & 625 \\
\hline B. vadoni & & 51 & 10 \\
\hline Brookesia spp. & 660 & & \\
\hline Total & 4,715 & 2,758 & 2,487 \\
\hline
\end{tabular}

period between 1996 and 2001 and CITES data total USD 56,170. The trade chain consists of three links, village collector, intermediary and exporter, with collectors receiving only $1.05 \%$ and intermediaries only $1.22 \%$ of the total income generated by the trade (Carpenter, 2003).

\section{Discussion}

It is likely that new species of Brookesia will be described in the near future (Glaw \& Vences, 2000), compounding current taxonomic problems in the genus, and potentially resulting in increased mislabelling, either accidental or intentional, on future consignments. Efforts should be made to assist the management authority of Madagascar to keep up to date with any future taxonomic changes and thus ensure species in consignments are correctly reported (Carpenter, 2002). CITES is currently in the process of conducting the first country-based review of significant trade, with Madagascar the focus country (Earth Negotiations Bulletin, 2004).

Well established management of trade should ensure that no collection is undertaken from protected areas. It would also permit an investigation of the impact of harvesting on abundance and demography; this is currently also required for 'true' chameleons. Current management practices in Madagascar have been shown to be detrimental to both conservation and poverty alleviation (Carpenter 2003; Carpenter et al., 2005). Management should implement economic and trade structures to allow local people to benefit from the trade whilst facilitating an income shift away from unsustainable forest practices (Carpenter et al., 2005).

The available information indicates that Brookesia are located on or close to the ground, with roost sites often $<1 \mathrm{~m}$ above ground, and many species have distinct altitudinal ranges and a preference for primary forest. Continued deforestation will therefore potentially lead to extirpations. Research is required on population sizes and seasonal trends of Brookesia, without which, combined with data on the impacts of harvesting, the establishment of sustainable trade will not be possible. This should be viewed as urgent for species that are traded. 
The addition of Brookesia to CITES Appendix II is precautionary. With limited information available on the genus, some of it contradictory, listing on CITES Appendix II was the only practical option. Trade in the genus was increasing both in numbers and diversity, distributions extremely local, and densities low in some species. The apparent reduction and possible cessation of trade in $B$. perarmata indicates that CITES can succeed in managing global trade in a threatened species.

\section{References}

Akani, G., Ogbalu, O. \& Luiselli, L. (2001) Life-history and ecological distribution of chameleons (Reptilia, Chamaeleonidae) from the rainforests of Nigeria: conservation implications. Animal Biodiversity and Conservation, 24, 1-15.

ANGAP (2001) Plan de gestion du reseau national des Aires Protegees de Madagascar. Association Nationale pour la Gestion des Aires Protégées, Antananarivo, Madagascar.

Brady, L. \& Griffiths, R. (1999) Status Assessment of Chameleons in Madagascar. IUCN/Species Survival Commission, UNEP/WCMC, Cambridge, UK.

Carpenter, A.I. (2002) CITES: Good Conservation or Failing All? Http:/ /www.chameleonnews.com/year2002/sept2002/ trade/trade.html [accessed 10 March 2004].

Carpenter, A.I. (2003) The ecology and exploitation of chameleons in Madagascar. PhD thesis, University of East Anglia, UK.

Carpenter, A.I., Robson, O., Rowcliffe, J.M. \& Watkinson, A.R. (2005) The impacts of international and national governance on a traded resource: a case study of Madagascar and its chameleon trade. Biological Conservation, 123, 279-287.

Carpenter, A.I., Rowcliffe, M. \& Watkinson, A. (2004) The dynamics of the global trade in chameleons. Biological Conservation, 120, 291-301.

Earth Negotiations Bulletin (2004) Summary of the 20th Meeting of the CITES Animals Committee: 29 March - 2 April 2004. Http:/ / www/iisd.ca/cites/CITA20/ [accessed 6 April 2004].

Glaw, F. \& Vences, M. (1994) A Field Guide to the Amphibians and Reptiles of Madagascar. 2nd edition. Privately published, Koln, Germany.

Glaw, F. \& Vences, M. (2000) Current counts of species diversity and endemism of Malagasy amphibians and reptiles. In Diversity and Endemism in Madagascar (eds W. Lourenco \& S. Goodman), pp. 243-248. Memoires de la Société de Biogeographie, Paris, France.

Glaw, F., Vences, M., Ziegler, T., Bohme, W. \& Kohler, J. (1999) Specific distinctness and biogeography of the dwarf chameleons Brookesia minima, B. peyrierasi and B. tuberculata (Reptilia: Chamaeleonidae): evidence from hemipenial and external morphology. Journal of Zoology, London, 247, 225-238.

Harwood, J. (1999) A Report on Annual Reports Submitted by the Parties to Cites. Unpublished Report. WCMC, Cambridge, UK.

IUCN (2004) 2004 IUCN Red List of Threatened Species. IUCN, Gland, Switzerland [http:/ / www.redlist.org, accessed 23 June 2005].

Jenkins, R.K.B., Brady, L.D., Bisoa, M., Rabearivony, J. \& Griffiths, R. (2003) Forest disturbance and river proximity influence chameleon abundance in Madagascar. Biological Conservation, 109, 407-415.
Jenkins, R.K.B., Brady, L.D., Huston, K., Kauffman, J.L.D., Rabearivony, J., Ravelson, G. \& Rowcliffe, M. (1999) The population states of chameleons within Ranomafana National Park, Madagascar, and recommendations for future monitoring. Oryx, 33, 38-46.

Jenkins, M. \& Broad, S. (1994) International Trade in Reptile Skins: A Review and Analysis of the Main Consumer Markets, 1983-91. TRAFFIC International, Cambridge, UK.

JNCC (1993) A Preliminary Review of the Status and Distribution of Reptile and Amphibian Species Exported from Madagascar. Report No.155, Joint Nature Conservation Committee, Peterborough, UK.

JNCC (2001) Checklist of Reptiles and Amphibians Listed in the CITES Appendices and in EC Regulation No. 338/97. Report No. 291, Joint Nature Conservation Committee, Peterborough, UK.

LeBerre, F. (1995) The New Chameleon Handbook: Everything about Selection, Care, Diet, Disease, Reproduction, and Behaviour. Barron's Educational Series, Hauppauge, New York, USA.

Necas, P. (1999) Chameleons: Nature's Hidden Jewels. Krieger Publishing, Florida, USA.

Rabearivony, J. (1999) Conservation and status of assessment of Brookesia, the dwarf chameleons of Madagascar. MSc thesis, DICE, University of Kent, UK.

Ramilison, O. \& Rabibisoa, N. (1998) Inventaire de l'Herpetofaune et etude d'impact sur les collectes de deux especies Reptiliennes, Brookesia perarmata (Chamaeleontidae) et Uroplatus henkeli (Geckonidae): Dans Le parc national No.7 'Tsingy De Bemaraha'. Unpublished Report, Madagascar.

Raxworthy, C. (1988) Reptiles, rainforests and conservation in Madagascar. Biological Conservation, 43, 181-211.

Raxworthy, C. \& Nussbaum, R. (1995) Systematics, speciation and biogeography of the dwarf chameleons (Brookesia; Reptilia, Squamata, Chamaeleontidae) of northern Madagascar. Journal of Zoology, London, 235, 525-558.

Rosser, A., Haywood, M. \& Harris, D. (2001) CITES: A Conservation Tool - A Guide to Amending the Appendices to the Convention on International Trade in Endangered Species of Wild Fauna and Flora. IUCN/Species Survival Commission, UNEP/WCMC, Cambridge, UK.

Uetz, P. (2004) Embl Reptile Database. Http:/ /www.emblheidelberg.de/ uetz/families/Chamaeleonidae.html [accessed 02 July 2004].

UK CITES (2004) EC CITES Scientific Review Group. Http://www.ukcites.gov.uk/news/ec_scient.htm [accessed 01 March 2004].

UNEP-WCMC (2005) UNEP-WCMC CITES Trade Database. Http:/ / www.unep-wcmc.org.uk/ [accessed 19 August 2005].

Whitmore, T. (2000) Madagascan deforestation rate during the 1980s. In Diversity and Endemism in Madagascar (eds W. Lourenco \& S. Goodman), pp. 125. Memoires de la Société de Biogeographie, Paris, France.

\section{Biographical sketches}

Angus Carpenter's research interests include conservation and wildlife biology, especially of reptiles. He conducted research on Malagasy chameleons over the last 4 years. His earlier research was conducted in Mauritius, Greece and the UK, on reptiles and birds.

Onja Robson is currently studying at the University of Anatananarivo, Madagascar. 